DOI: 10.22616/REEP.2019.029

\title{
Research of Nutritional Habits of Prospective teachers
}

\author{
Inga Kepaliene ${ }^{1}$ Dr.; Diana Gudaviciute ${ }^{2}$ Dr. \\ Vytautas Magnus University Education Academy, Lithuania \\ inga.kepaliene@vdu.1t ${ }^{1}$; diana.gudaviciute@vdu.1t ${ }^{2}$
}

\begin{abstract}
In modern society healthy nutrition is a particularly topical issue as it is one of the key elements of a healthy lifestyle which determines a person's well-being. One of the tasks established in the European Region Health Policy "Health for All in the 21st Century" is to promote habits of healthy nutrition. The goal of the research is to identify nutritional habits of the prospective teachers. 631 prospective teachers studying at Vytautas Magnus University took part in the questionnaire survey. The period of studies is closely related to the study process, the change of the place of residence, and that often adversely affects the dietary regime. Nutritional habits during the study period are partly formed by the training institution as well as the food culture tradition spread among the students. Involvement in activities and the change of the place of residence influenced nutritional habits of prospective teachers. Having analysed the survey data, it is possible to state that most students - prospective teachers - choose food considering its taste characteristics and the price. The students choose various food products and try to follow the recommendations for healthy nutrition.
\end{abstract}

Keywords: nutritional habits, prospective teachers, university education.

\section{Introduction}

Researchers pay particular attention to strengthening healthy nutrition and healthy lifestyle as that is one of the key elements of a healthy lifestyle which determines a person's well-being.

One of the objectives of World Health Organization (WHO) European Region Health Policy "Health for All in the 21 st Century" is by 2020 to improve health of young people so that they could play their role in the society more successfully (Health 2020..., 2013). Moreover, healthy and employable people are a guarantee for the country's economic and sustainable development; therefore, preservation and strengthening of the health of children and young people is emphasized in the strategic documents of the country (Lithuania's Progress Strategy..., 2012). Prospective teachers should take particular care of their nutrition because they will serve as an example for their students in the future.

A study period is a segment of the social life related with a number of new challenges, new impressions and habits, formation of lifestyle changes; therefore, students' nutrition is of great interest for many researchers (Porozovs, 2018). Proper nutrition provides a human with energy, necessary nutrients which ensure proper physical condition, permanent cell regeneration whereas poor nutrition increases a risk of development of chronic cardiovascular diseases (Hughes, 2012). According to H. Baker-Henningham, S. Grantham-McGregor (2004), healthy nutrition is one of the key elements of healthy lifestyle, it helps to preserve and strengthen health, to prevent many diseases, and it is the basis of health.

Recently, a large number of researches analysing students' nutrition have been conducted. Several authors carried out the assessment of students' nutritional habits (Dobrovolskij, Stukas, 2013; Ansari, Stock, Mikolajszyk, 2012; Plavina, Karklina, 2018) and researched the indices of students' healthy lifestyle from various perspectives (Varela-Mato et al., 2012; Zheng et al., 2014).

One of the most important factors determining human health and quality of life is proper nutritional habits, whereas unbalanced nutrition impacts the development of certain diseases, incidence of chronic non-infectious diseases (e. g. diabetes mellitus, cardiovascular diseases, etc.) as well as increases mortality. Nutrition is becoming a very important factor affecting all age groups. Assessing the pathogenesis of many diseases in every stage of life, balanced nutrition and proper habits have a favourable impact on human health (Cecchini et al., 2010).

R. Proskuviene, J. Cesnaviciene (2015) researched nutritional peculiarities of young people who have chosen pedagogical studies. The research data demonstrated that 68.5 percent of young people who have chosen pedagogical studies consider healthy nutrition important and state that they try to eat healthy. However, the research also revealed that a significant share of students do not have the formed healthy 
nutritional habits and do not follow the recommendations for healthy nutrition. The goal of the research is to identify nutritional habits of prospective teachers.

\section{Methodology}

In order to research nutritional habits of prospective teachers a quantitative research was carried out, and a questionnaire survey method was chosen. The research took place in March - April 2017. 631 prospective teachers of the Groups of the Study Programmes of Natural Science Education (NSE), Sports Education (SE), Pre-School and Primary Education (PSPE), Linguistic and Artistic Education (LAE) of Vytautas Magnus University (former Lithuanian University of Educational Sciences) participated in the questionnaire survey. $1^{\text {st }}-4^{\text {th }}$ year students participated in the research: 451 girls and 180 boys.

The students took part in the survey voluntarily, and the questionnaire was anonymous so that the respondents could express their viewpoint unreservedly. The goals and methodology of the research were explained to the students.

To research nutritional habits of prospective teachers, a theoretical analysis of scientific literature was conducted first and accordingly a semi-closed questionnaire was created. It consisted of a demographic data block (data of the researched subjects) and a block of closed and open questions in order to research nutritional peculiarities of the students. The questions were about the day's routine and dietary regime, nutritional habits, consumed food products and drinks, and the causes of unhealthy nutrition.

The statistical data were processed using the SPSS (Statistical Package for Social Sciences, 17.0) programme.

\section{Results and Discussion}

The day's routine is an integral complex of healthy lifestyle factors that has an impact on nutritional habits. The students had an opportunity to write down the day's routine of working days and rest days (Table 1). The research aimed at finding out the day's routine of prospective teachers as well as identifying the factors potentially affecting the students' nutritional habits. The obtained results demonstrate that students spend 3-6 hours at the university; however, they spend not less time for individual studies, i. e. 2-5 hours per day. According to the respondents, from 2 to 7 hours a day are devoted to leisure. At weekends and on holidays students can afford to relax longer - from 10 to 15 hours. The approximate sleep duration is from 6 to 10 hours: that depends on the day of the week and the day's routine.

Table 1

Students' Day's Routine

\begin{tabular}{|l|c|}
\hline \multicolumn{1}{|c|}{ Activities } & Hours/ per day \\
\hline Time spent at the university & $3-6$ hours \\
\hline Time devoted to individual studies & $2-5$ hours \\
\hline $\begin{array}{c}\text { Duration of leisure time: } \\
\text { on working days } \\
\text { at weekends / on holidays }\end{array}$ & $2-7$ hours \\
$10-15$ hours \\
\hline Sleep duration & $6-10$ hours \\
\hline
\end{tabular}

Having summarized the results of the survey, it can be stated that one of the factors influencing nutritional habits is prospective teachers' involvement in activities.

In order to learn about nutritional habits, the students were asked: "Do you cook food yourself?" (Figure 1). The results of the survey demonstrated that 96 percent of the students living in rented accommodations and 94 percent of those living in dormitories cook food themselves; however, 92.9 percent of the students living together with parents / foster-parents do not cook food themselves.

The results of the research revealed that the students living separately from their parents cook food themselves, whereas the students living with their parents / foster-parents choose the food cooked by others $\left(\chi^{2}=2.768 ; \mathrm{df}=2 ; \mathrm{p}<0.251\right)$. 


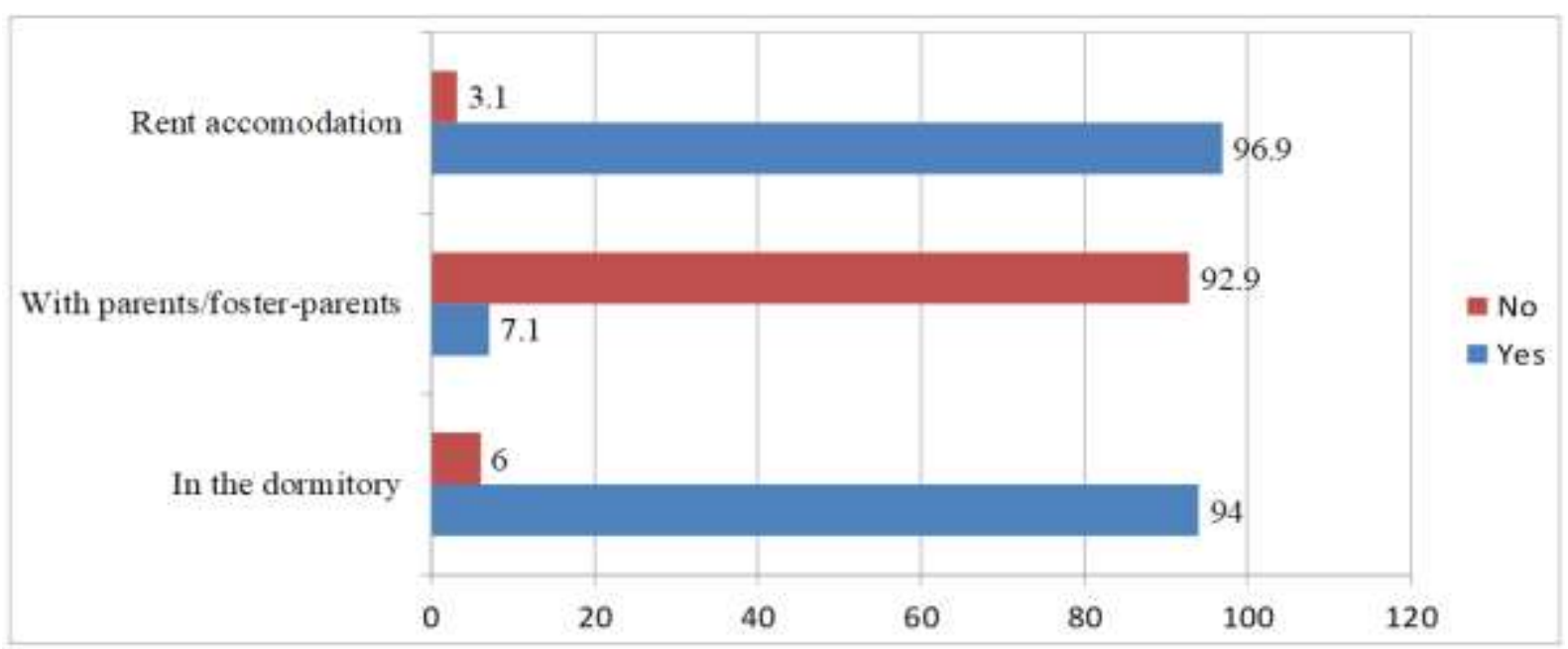

Figure 1. Distribution of the students" answers to the question "Do you cook food yourself?" (percent).

WHO recommendations indicate that an adult person should eat three or four times a day: breakfast, lunch (or to have afternoon meal), lunch and dinner. A human needs most energy during the day when she or he works or studies. In order to find out the rhythm of nutrition, the respondents were asked a question: "How often do you eat a day?" The obtained survey data showed that most students of all groups of the study programmes have breakfast, lunch and dinner: NSE - 91.1 percent, LAE - 89.3 percent, SE - 75 percent, and PSPE - 80 percent. Only minority of the students have breakfast and dinner only or do not have breakfast at all. Thus, it can be stated that students try to eat rationally - three or four times a day, no statistically significant differences between groups of the study programmes were established $\left(\chi^{2}\right.$ $=22.657 ; \mathrm{df}=4 ; \mathrm{p}<0.000)$. R. Proskuviene and J. Cesnaviciene researched nutritional habits of students (prospective teachers) (Proskuviene, Cesnaviciene, 2015). The results of the research demonstrated that only 61.1 percent of the students had breakfast every day, 24.8 percent of the respondents did their best to eat at the same time, and 15 percent of young people ate only 1-2 times a day.

We asked how much time students spend for lunch on the average. The survey data demonstrate that on the average students spend 20 minutes for lunch.

Snacking is the most common students' habit in their leisure time; therefore, when analysing nutritional habits, it is important to identify which food products are chosen as snacks. Thus, the students were asked a question: "What snacks do you choose between breakfast, lunch and dinner?", and options for possible answers were provided (Figure 2).

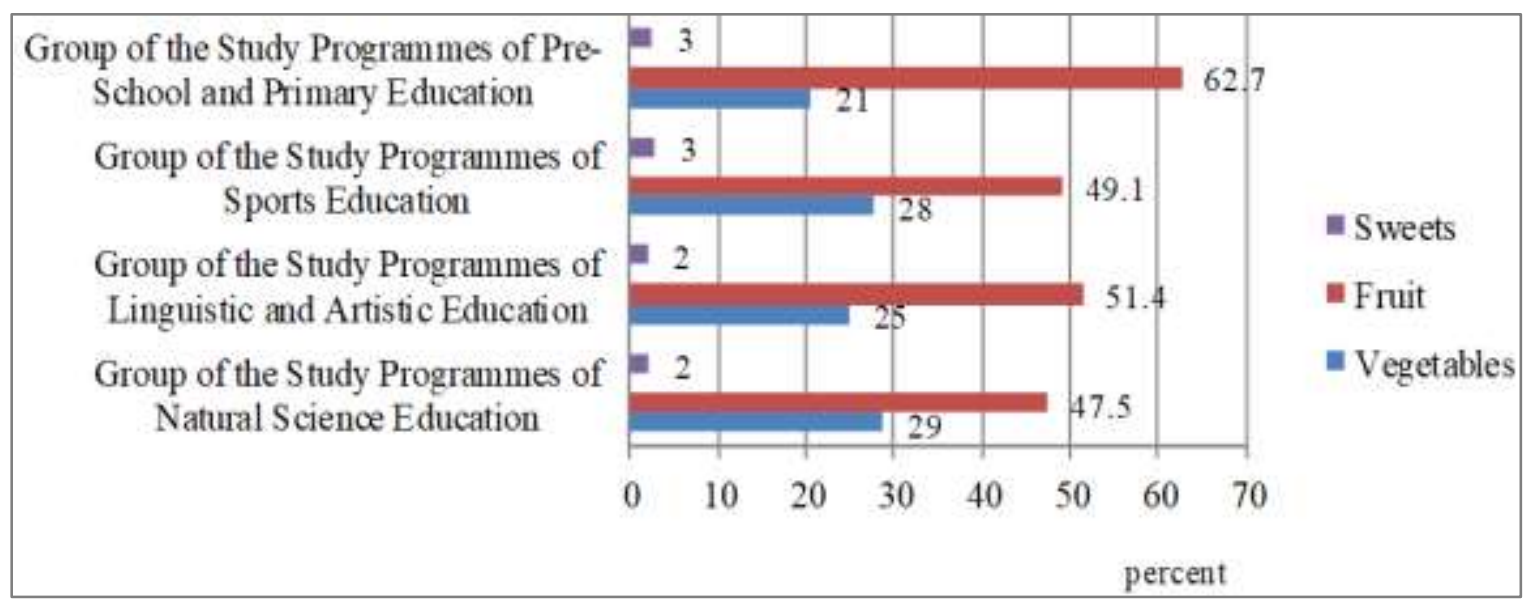

Figure 2. Distribution of the students" answers to the question "What snacks do you choose between breakfast, lunch and dinner?" (percent).

The results of the survey demonstrated that usually students tend to choose fruit as snacks: PSPE - 62.7 percent, LAE - 51.4 percent, SE - 49.1 percent, and NSE - 47.5 percent. 25.7 percent of the respondents 
choose vegetables, 19.5 percent of the research participants snack on chips, and only a small share of the respondents prefer nuts and sweets.

Water is a vitally necessary nutritional component that performs very important physiological functions in the body. Therefore, the research aimed at finding out whether students follow WHO recommendations to drink pure water (Figure 3). The obtained research results demonstrate that less than half of the surveyed prospective teachers choose water, 37.6 percent stated that they usually drink coffee or tea. Only a small share of the respondents prefers juice -2.5 percent.

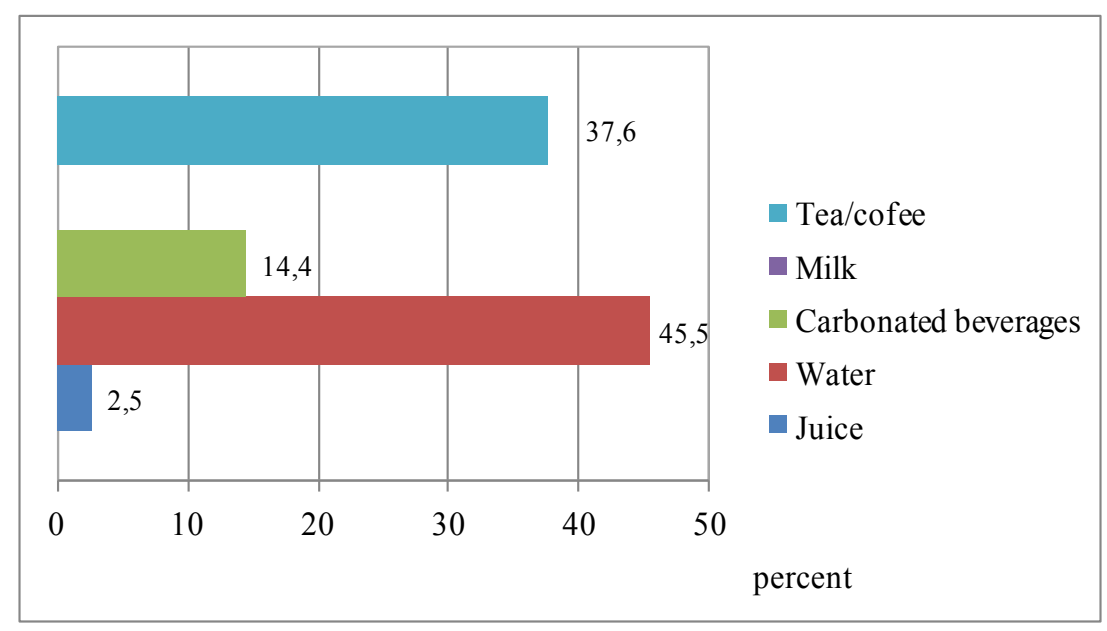

Figure 3. Distribution of the students' answers to the question "What drinks do you choose?" (percent).

One of the goals of the research was to find out the frequency of consumption of beverages which are harmful for health; therefore, the respondents were asked a question: "How often do you consume energy drinks?" and options for possible answers were provided. It turned out that 36.5 percent of the students consume these beverages more than 3 times a week, 20 percent of the students drink them 1-2 times a week, and 7.4 percent of the students do not refuse energy drinks several times a year.

Analysing the students' nutritional habits, it is important to determine how much water students drink per day. In WHO recommendations it is emphasized that an adult person is recommended to drink 2 litres of water a day, i. e. about 8 glasses. The obtained results of the research show that more than one third of the respondents (35.4 percent) drink 1 litre of water per day, i. e. a half of the recommended amount, and only 29.3 percent consume 2 litres of water, i. e. a full daily intake.

More and more attention is paid to the quality of food products. Having compared the main criteria according to which the respondents of all four groups of the study programmes were choosing food products, it turned out that most prospective teachers first of all take into account taste characteristics of food products: PSPE - 52 percent, LAE - 48.6 percent, SE - 47.2 percent, and NSE -44.6 percent.

Another integral factor determining the choice of the respondents is the price of the product ( $\mathrm{SE}-22$ percent, NSE - 20.8 percent, PSPE - 20.6 percent, and LAE - 20.6 percent). A tendency was observed that girls are concerned about health improvement more than boys $(\mathrm{p}<0.05)$.

Seeking to find out the students' nutritional habits, to determine what they eat, a list of products and options for possible answers were provided. The results of the research demonstrated that students eat fish products at least once a week (42.8 percent), although it is recommended to eat fish twice or three times. A share of the respondents chooses smoked meat products ( 33 percent) once a week, cereal products $(28.2$ percent) and potatoes $(28.2$ percent $)$ - once or twice a week. The analysis of the survey showed that one third (35.5 percent) of the students receive fat together with food.

According to the research data, most frequently, i. e. 3-5 times a week, the respondents eat fresh vegetables -51.3 percent, meat products -40.9 percent and milk products -30.4 percent. Thus, it can be stated that students, except the cases when they lack time, try to follow the recommendations for healthy nutrition. 
To find out what determines unhealthy nutrition, the respondents were asked a question: "What, in your opinion, are possible reasons of unhealthy nutrition?" Having analysed the answers, it was established that lack of time has the greatest impact on inappropriate nutritional habits of the respondents -65.8 percent, almost half of the respondents having participated in the survey (49.3 percent) partly agree that the choice is influenced by negative influence of advertisements, and 35.3 percent of the respondents indicated that unhealthy nutritional habits are determined by the financial situation. In the opinion of more than half (51.8 percent) of the respondents, unhealthy nutrition does not have any negative impact on their health in general.

According to the data of the conducted analysis, two most important factors determining unhealthy nutrition are: lack of time (identified by 65.8 percent of the respondents) and lack of will (51.8 percent of the respondents).

\section{Conclusions}

1. The period of studies is closely related to the study process, the change of the place of residence, and that often adversely affects the dietary regime. Nutritional habits during the study period are partly formed by the training institution as well as the food culture tradition spread among the students. Studies are associated with students' involvement in numerous activities, mental and physical activity, and the assumed responsibility for purchasing food and cooking has a negative impact on students' nutritional habits: frequently young people do not pay sufficient attention to their health, do not have enough time to eat, do not follow dietary regime.

2. About a half of the surveyed students of NSE, SE, LAE and PSPE having started to study changed their nutritional habits. Majority of the students of all the groups of the study programmes (75 - 91 percent) indicated that they follow their dietary regime, a big share of the students (70 percent.) devote 20 minutes for having lunch, more than a half of the students $(47.5$ - 62.7 percent) tend to choose some fruit for a snack, and less than one-third of the students (25.7 percent) prefer vegetables. Only 19.5 percent of the surveyed students eat chips as a snack. Having analysed the survey data, it is possible to state that most students choose food considering its taste characteristics and the price. The students choose various food products and try to follow the recommendations for healthy nutrition.

3. Involvement in activities and the change of the place of residence influenced nutritional habits of the prospective teachers. The main factors having impact on the formation of inappropriate nutritional habits indicated by the prospective teachers were the following ones: lack of time (65.8 percent) and the financial situation ( 35.5 percent), a provision that unhealthy nutrition will not harm them (37.5 percent). Having compared the obtained results among all groups of the study programmes, statistically significant differences were not found.

\section{Bibliography}

1. Ansari W.E., Stock C., Mikolajszyk R.T. (2012). Relationships Between Food Consumption and Living Arrangements Among University Students in Four European Countries - A cross-sectional study. Nutrition Journal, 11, 28. Retrieved from

https://nutritionj.biomedcentral.com/articles/10.1186/1475-2891-11-28

2. Baker-Henningham H., Grantham-McGregor S. (2004). Nutrition and Child Development. In M.M.J. Gibney, M.B. Margetts, J.M. Kearney, L. Arab (Eds.), Public Health Nutrition, 247-263.

3. Cecchini M., Sassi F., Lauer J.A., Lee Y.Y., Guajardo-Barron V., Chisholm D. (2010). Tackling of Unhealthy Diets, Physical Inactivity, and Obesity: Health Effects and Cost-Effectiveness. Lancet, 376, 1775-1784. Retrieved from

https://www.who.int/choice/publications/Obesity_Lancet.pdf

4. Dobrovolskij V., Stukas R. (2013). Lithuanian Population's Eating Habits in 2013. Health sciences, 23, 4(89).

5. Health 2020: a European Policy Framework and Strategy for the 21st Century. (2013). Copenhagen, Denmark: World Health Organization. Retrieved from http://www.euro.who.int/_data/assets/pdf_file/0011/199532/Health2020-Long.pdf

6. Hughes R. (2012). Food Insecurity Amongst University Students. Nutridate, 23(2), 2-4. 
7. Lithuania's Progress Strategy "Lithuania 2030“. (2012). Retrieved from https://www.docdroid.net/ERhjMs3/en-lietuva2030.pdf

8. Plavina L., Karklina H. (2018). Physical Activity and Life Quality of Part-Time Students. In V. Dislere (Ed.), The Proceedings of the International Scientific Conference Rural Environment. Education. Personality (REEP), 11. Jelgava: LLU TF, 395-400. Retrieved from http://llufb.llu.lv/conference/REEP/2018/Latvia_REEP_2018_proceedings_ISSN2255808X395-400.pdf

9. Porozovs J. (2018). Lifestyle Peculiarities of Riga Basic School and University Students. In V. Dislere (Ed.), The Proceedings of the International Scientific Conference Rural Environment. Education. Personality (REEP), 11. Jelgava: LLU TF, 314-320. Retrieved from http://llufb.llu.lv/conference/REEP/2018/Latvia_REEP_2018_proceedings_ISSN2255808X314-320.pdf

10. Proskuviene R., Cesnaviciene J. (2015). Pedagogines studijas pasirinkusiu jaunuoliu mitybos ypatumai (Dietary Peculiarities of Youths Who Have Chosen Pedagogical Studies). Visuomenes sveikata, 1(68), 68-77. (in Lithuanian)

11. Varela-Mato V., Cancela J.M., Ayan C., Martin V., Molina A. (2012). Lifestyle and Health Among Spanish University Students: Differences by Gender and Academic Discipline. International Journal of Environmental Research and Public Health, 9(8), 2728-2741.

12. Zheng X.Y., Han Y.L., Guo C., Zhang L., Qui Y., Chen G. (2014). Progress in Research of Nutrition and Life Expectancy. Biomedical Environmental Science, 27(3), 155-161. Retrieved from https:/www.sciencedirect.com/science/article/pii/S0895398814600283 